\title{
Institutions, Informal Economy and Economic Development
}

\author{
Ceyhun Elgin* \\ Bogazici University
}

\author{
Ŏguz Öztunalı ${ }^{\dagger}$ \\ Bogazici University
}

\begin{abstract}
Using cross-country panel data we examine the evolution of the informal economy through the course of economic development by particularly taking its relationship with institutions into account. We borrow from the informal economy estimates constructed by Elgin and Oztunali (2012) for 141 countries over the period from 1984 to 2009 and using panel data estimation techniques we investigate the relationship between informal economy and the level of economic development, proxied by GDP per-capita. Our findings suggest that institutional quality strongly interacts with the relationship between economic development and size of the informal economy. Specifically, we find that a higher GDP percapita is associated with a larger informal sector size in countries where the institutional quality is low. The opposite is true in countries with good institutions. These results are also in line with a two-sector dynamic general equilibrium model of the informal economy.
\end{abstract}

JEL codes: E32, O17, O41.

Keywords: informal economy, institutions, panel data.

*Address: Bogazici University, Department of Economics, Natuk Birkan Building, 34342 Bebek, Istanbul, (Turkey). e-mail: ceyhun.elgin@boun.edu.tr.

${ }^{\dagger}$ Address: Bogazici University, Department of Economics, Natuk Birkan Building, 34342 Bebek, Istanbul, (Turkey). e-mail: oguz.oztunali@boun.edu.tr. 


\section{Introduction}

Informal economy, sometimes also titled shadow, hidden, black, parallel, second or underground economy (or sector) is defined by Hart (2008) as a set of economic activities that takes place outside the framework of bureaucratic public and private sector establishments not in compliance with government regulations. Moreover, remembering a very frequently cited definition of institutions by North (1991) that "Institutions are the humanly devised constraints that structure political, economic and social interaction" it would be a mistake to overlook what is potentially the strongest determinants of informality and tax evasion: quality of institutions. These definitions led most people in the literature to argue that informal economy would disappear as a result of economic progress in developing countries. The main assumption behind this conjecture was that economic progress, followed by or going along with improvement in institutional quality would reduce incentives of firms and households to go informal.

Aiming to analyze the behavior of the informal sector and its interaction with institutional quality over the development path of an economy, in this paper we investigate the validity of this conjecture both theoretically and empirically. Theoretically, we intend to develop a model of informal economy that we can then use to investigate the relationship between GDP per-capita and informal economy size. Particularly, we try to find whether there is a straightforward negative relationship between informal economy size and economic progress measured by GDP per-capita ${ }^{1}$, or whether this negative relationship is conditional on the introduction of additional dimensions related to the development process, such as the quality of institutions. The two-sector dynamic general equilibrium model we construct for this purpose indicates that institutional quality strongly interacts with the relationship between GDP per-capita and informal economy size. Specifically, we find that higher GDP per-capita levels

\footnotetext{
${ }^{1}$ Even though it might be viewed as an imperfect measure of the level of "development", throughout the paper we use GDP per-capita as a proxy for economic development.
} 
are associated with larger informal sectors in countries with low institutional quality, whereas the size of the informal sector is negatively associated with GDP per-capita in countries where institutional quality is high. Moreover, we also empirically study the relationship between the size of the informal economy, GDP per-capita and various indicators of the institutional environment. As for the empirical contribution of our paper, one should first notice that empirical studies on informality are rare because of limited data availability, since informality is hard to measure by definition. The largest data set in the literature was the one constructed by Buehn and Schneider (2012a), including data from 162 countries but only for 9 years (from 1999 to 2007). However, institutional quality, which is one of the central components of our empirical analysis, does not vary much over a short time horizon such as 9 years. Since we aim to examine the evolution of the shadow economy through the course of development by particularly taking its relationship with institutions into account, we borrow from the shadow economy estimates constructed by Elgin and Oztunali (2012) for 161 countries over the period from 1950 to 2009. Then, using panel data estimation techniques we investigate how the size of the shadow economy changes in the progress of economic development with varying institutional quality. Our results indicate that institutional quality strongly interacts with the relationship between economic development and informal economy size in the way suggested by our theoretical model.

The rest of the paper is organized as follows: In the next section, we shortly review the related literature. Then, in the third section, we describe a theoretical environment based on a two-sector dynamic general equilibrium model, define an equilibrium and characterize it. In the fourth section, we conduct numerical simulations of the model, particularly focusing on the relationship between informal economy size and GDP per-capita with varying institutional quality. Next, in the fifth section, we present results of several regressions supporting the predictions of the model and our hypothesis. Finally, we provide concluding remarks and a short discussion. 


\section{Related Literature}

The effects of the informal economy on economic progress, instead of the reverse mechanism that is studied in this paper, is explored to some extent in the literature. Using firm-level data, Raj and Seethamma (2007), Byiers (2009) and Taymaz (2009) find high productivity differences between formal and informal firms, in favor of formal firms, and regard the low productivity levels of the informal firms as an obstacle against growth. On the other hand, according to La Porta and Schleifer (2008), while the source of economic growth is generally highly productive formal firms, informal firms provide livelihood for the poor but face extinction eventually. Aside from the low productivity argument, Gatti and Honoratti (2008), Caro, Galindo and Meléndez (2012) and Dabla-Norris and Koeda (2008) find that higher levels of informality in various forms are associated with less access to credit, an important determinant of economic performance.

There are also various papers that study the effects of the institutional environment on informal economy size. Torgler and Schneider (2009) and Aruoba (2010) find negative relationships between various some measures of institutional quality and the size of the informal sector. In another related study Johnson et al. (1998) indicate that the effectiveness of government officials' discretion in the functioning of the regulatory system is a main determinant of the size of the informal economy. Similarly, Feld and Schneider (2010) focus on the effects of the design of tax policies and state regulation. Again on the fiscal side of the policy, Buehn, Lessman and Markwardt (2013) illustrate that fiscal decentralization is one of the key determinants of informality. However, in contrast to the common argument that higher taxes induce informality, Friedman et al. (2000) find that the level of informality mainly depends on over-regulation and corruption in a positive manner, whereas Singh et al. (2012) show that there is a negative relationship between the rule of law and the size of the informal economy. As a study on the political determinants of 
informality, Schneider and Teobaldelli (2012) indicate that the degree of direct democracy is negatively associated with the size of the shadow economy. In another related study, Buehn and Schneider (2012b) find that corruption and the shadow economy are complements rather than being substitutes.

Somewhat more closely related to our paper, Dell'Anno (2010) shows that institutional quality is one of the key indicators of informality in Latin American economies. Moreover, he also finds evidence towards the existence of an inverted-U relationship between human development and informal economy size.

Even though largely related to the papers shortly summarized above, our paper is distinct in a number of ways and has a significant contribution to the literature: First, our paper is the first paper investigating the relationship between informal economy, GDP per-capita and institutions using a dynamic general equilibrium framework. Second, considering the fact that most of the empirical papers only use a limited number of countries with a significantly limited time-series dimension (5-10 years), among the empirical papers investigating relates issues, our paper is the one utilizing the largest dataset up to date. Finally, another contribution is that we both theoretically and empirically identify a novel relationship between informal economy size, institutional quality and GDP per-capita, that has not been identified and accounted for before in the literature.

\section{A Theoretical Framework}

\subsection{Model Environment}

We consider a two-sector dynamic general equilibrium model with a formal and informal sector. ${ }^{2}$

In this environment, the representative household solves the following infinite horizon utility maximization problem:

\footnotetext{
${ }^{2}$ Simple versions of this model is used by Busato and Chiarini (2004), Roca et al. (2001) and Elgin (2010).
} 


$$
\begin{aligned}
\max _{\left\{C_{t}, K_{t+1}, N_{I t}, N_{F t}\right\}_{t=0}^{\infty}} & \sum_{t=0}^{\infty} \beta^{t}\left[\log \left(C_{t}\right)+\phi \log \left(T-N_{I t}-N_{F t}\right)\right] \\
\text { subject to } & C_{t}+K_{t+1}-(1-\delta) K_{t}=(1-\tau) \theta_{F} K_{t}^{\alpha} N_{F t}^{1-\alpha}+(1-\rho \tau) \theta_{I} N_{I t}^{\gamma}
\end{aligned}
$$

In the above specification, in each period, the stand-in household makes consumption and investment decisions, and allocates labor to formal and informal sectors. To do this, she derives utility from consumption, denoted by $C_{t}$, and from leisure which is denoted by $T-N_{I t}-N_{F t}$. $K_{t}$ stands for physical capital, $\delta$ for depreciation of physical capital and $T$ denotes the total time endowment. $\phi$ represents the weight given to leisure in the household's utility function. The first term on the right hand is the income from formal sector production net of taxes $\tau$ and the second term is the income from informal sector production. Here, $\theta_{I}$ and $\theta_{F}$ stand for total factor productivities (TFP) of informal and formal sector, respectively. $N_{F t}$ stands for labor devoted to the formal sector while $N_{I t}$ denotes labor devoted to the informal sector. Taxes are not enforced in the same degree across both sectors. The degree of tax enforcement on the informal sector is denoted by $\rho$ where $\rho \in[0,1]$. The sum of taxes collected from both sectors is equal to the government spending $G_{t}$ which is thrown away. ${ }^{3}$

Now, given this environment, we can define the competitive equilibrium as follows:

Definition 1. Given the government policy variables $\{\tau, \rho\}$, an equilibrium of this two-sector model is a set of sequences $\left\{C_{t}, l_{t}, K_{t+1}, N_{I t}, N_{F t}, G_{t}\right\}_{t=0}^{\infty}$ such that

1. The representative household chooses $\left\{C_{t}, l_{t}, K_{t+1}, N_{I t}, N_{F t}\right\}_{t=0}^{\infty}$ to maximize life-time utility.

2. $G_{t}$ equals $\tau \theta_{F} K_{t}^{\alpha} N_{F t}^{1-\alpha}+\rho \tau \theta_{I} N_{I t}^{\gamma}$ and is thrown away.

\footnotetext{
${ }^{3}$ Endogenizing the government's decision in an optimal taxation framework would not change our results qualitatively. (See Elgin, 2010 and Elgin and Solis-Garcia, 2012.
} 


\subsection{Characterization}

Given the definition of the competitive equilibrium, first-order conditions of the model can be manipulated to obtain the following:

$$
\begin{gathered}
\frac{C_{t+1}}{C_{t}}=\beta\left[(1-\tau) \theta_{F} \alpha K_{t+1}^{\alpha-1} N_{F t+1}^{1-\alpha}+1-\delta\right] \\
(1-\tau) \theta_{F}(1-\alpha) K_{t}^{\alpha} N_{F t}^{-\alpha}=(1-\rho \tau) \theta_{I} \gamma N_{I t}^{\gamma-1}
\end{gathered}
$$

The first equation is the standard Euler equation and the second equation represents the condition that the net marginal products of labor in both sectors should be equal at the optimum. Imposing the steady state to the two equations given above, the following expression which characterize the steady state informal and formal labor are obtained:

$$
\begin{gathered}
N_{I}=\left\{\frac{(1-\rho \tau) \gamma \theta_{I}}{(1-\tau)(1-\alpha) \theta_{F}}\left[\frac{1 / \beta-1+\delta}{\alpha(1-\tau) \theta_{F}}\right]^{\frac{\alpha}{1-\alpha}}\right\}^{\frac{1}{1-\gamma}} \\
N_{F}=\frac{\left(T-N_{I}\right) \gamma(1-\rho \tau) \theta_{I} N_{I}^{\gamma-1}-\phi(1-\rho \tau) \theta_{I} N_{I}^{\gamma}}{\gamma(1-\rho \tau) \theta_{I} N_{I}^{\gamma-1}+\phi\left[(1-\tau) \theta_{F}\left(\frac{\alpha(1-\tau) \theta_{F}}{1 / \beta-1+\delta}\right)^{\frac{\alpha}{1-\alpha}}-\delta\left(\frac{\alpha(1-\tau) \theta_{F}}{1 / \beta-1+\delta}\right)^{\frac{1}{1-\alpha}}\right]}
\end{gathered}
$$

Notice that, given these equations, every variable of the model at the steady state can now be expressed as functions of the exogenous parameters. With all these variables at hand, we can also express the informal economy as $\%$ of GDP, i. e. $\frac{\theta_{I} N_{I t}^{\gamma}}{\theta_{F} K_{t}^{\alpha} N_{F t}^{1-\alpha}}$.

As the expressions are highly rich in terms of the parameters, it is not possible to obtain a further analytical result with respect to the relationship between informal economy size and GDP per-capita (i.e. formal output). This is why we will present results of numerical simulations using the model generated series in the next section. 


\section{Numerical Analysis}

Our ultimate aim in this section is to provide some (numerical) comparative statics results with respect to the size of the informal economy. Particularly, we intend to see how informal economy size as $\%$ of GDP, i.e. $\frac{\theta_{I} N_{I t}^{\gamma}}{\theta_{F} K_{t}^{\alpha} N_{F t}^{1-\alpha}}$ changes when GDP per-capita $\theta_{F} K_{t}^{\alpha} N_{F t}^{1-\alpha}$ varies. ${ }^{4}$ However, notice that both informal and formal outpus are endogenous in the model. This means that we need to create a variation in at least one parameter of the model to create some variation in these two variables. We intend to create such a variation by varying two specific non-standard parameters of the model which will represent institutional quality within the economy.

Choosing the right values for parameters is key to a numerical simulation of a model. In this case, we follow Ihrig and Moe (2004) and set $\alpha=0.33$, $T=100, \beta=0.97, \gamma=0.495$ and $\delta=0.08$. Moreover, we calibrate $\phi=0.12$ to match the average informal economy size (as \% of GDP) in our dataset. ${ }^{5}$ Then, finally, to vary institutional quality, we fix the formal sector TFP parameter $\theta_{F}$ and the tax enforcement parameter $\rho$ initially at numeraire and assume that $\theta_{I}=6^{6}$.

\section{Figures 1 and 2 about here}

To mimic an economic environment with decreasing institutional quality, in every step of the simulation, we reduce $\rho$ by $10 \%$ in grids from 1 to 0 , and increase $\frac{\theta_{I}}{\theta_{F}}$ by $10 \%$ in grids of 0.6 . This corresponds to an economy with deteriorating institutions where the degree of tax enforcement gets smaller and the informal sector TFP parameter increases relative to the formal sector one. ${ }^{7}$

\footnotetext{
${ }^{4}$ As there is no population growth in the model GDP and GDP per-capita do not differ.

${ }^{5}$ More discussion on the data will be made in the next section.

${ }^{6}$ Such a value of the informal sector TFP parameter is in line with the firm-level studies summarized in the introduction

${ }^{7}$ Remembering the forms of the production functions, as we do not have government spending as an input in the functions, increasing the ratio of TFPs might be interpreted as the reducing quality of government spending, a further indicator of institutional quality. Moreover, results would not change if we had varied $\rho$ or $\frac{\theta_{I}}{\theta_{F}}$ separately.
} 
Similarly, to mimic an economic environment with improving institutional quality, in every step of the simulation, we increase $\rho$ by $10 \%$, and keep $\frac{\theta_{I}}{\theta_{F}}$ constant. Notably, we use the ratio of TFPs in both sectors and the level of tax enforcement proxies for institutional quality. Specifically, a higher value for the ratio of $\theta_{F}$ to $\theta_{I}$ and $\rho$ would be equivalent to an environment with better institutions. ${ }^{8}$

Figure 1 plots the size of the informal economy as $\%$ of formal output against the formal output with deteriorating institutional quality, whereas Figure 2 plots the same series with improving institutional quality. According to the simulations, the relationship between informal economy size and GDP per-capita strongly interacts with institutional quality. That is, with low quality of institutions, economic growth does not reduce informality, instead informal economy growth along with the formal one.

Having numerically simulated the model, in the next section we will turn to empirical analysis, in which we aim to see whether the results suggested by the model are empirically supported by the data or not. In other words, we intend to empirically test the above suggested hypotheses using panel and cross-country regressions. Specifically, in the empirical analysis we intend to show that a higher level of GDP per-capita is associated with

1. a larger informal economy size when the level of institutional quality is low,

2. a smaller informal economy size when the level of institutional quality is high.

\section{Empirical Analysis}

Our ultimate purpose in this section is to show support for the theory that institutional quality strongly interacts with GDP per-capita in the latter's relationship with informal economy size.

\footnotetext{
${ }^{8}$ This assumption is also used by various others such as Blanchard Wolfers, 1999; Crafts and Kaiser, 1004 and Charles, 2011 among many others.
} 


\subsection{Econometric Framework}

Given the panel structure of our data, in our benchmark analysis we will estimate following regression equation:

$$
I S_{i, t}=\sigma_{0}+\sigma_{1} G D P_{i, t}+\sigma_{2} G D P_{i, t} \cdot \text { Inst }_{i, t}+\sum_{k=3}^{n} \alpha_{k} X_{k i, t}+\mu_{i}+\gamma_{t}+\epsilon_{i, t}
$$

Here, and $I S_{i, t}$ is the informal economy size as $\%$ of GDP in country $i$ in year $t$ and GDP denotes GDP per-capita. Moreover, $X_{k_{i, t}}$ are the other explanatory variables used as controls and $\mu_{i}, \gamma_{t}$ are the country and period fixed effects, respectively. Finally, $\epsilon_{i, t}$ denotes the error term.

In the benchmark case, we use the fixed-effects (FE) estimator as the Hausman test points us in favor of this specific estimator. However, to capture persistence and also potentially mean-reverting dynamics in the informal sector size, we also report results of the dynamic panel data estimation using the GMM estimator developed by Arellano and Bond (1991) where one-period lagged values of the regressors are used as instruments to avoid endogeneity. In this case we estimate the following equation:

$I S_{i, t}=\sigma_{0}+\sigma_{1} G D P_{i, t}+\sigma_{2} G D P_{i, t} \cdot$ Inst $_{i, t}+\sigma_{3} I S_{i, t-1}+\sum_{k=4}^{n} \sigma_{k} X_{k i, t}+\mu_{i}+\gamma_{t}+\epsilon_{i, t}$

In the dynamic panel data estimations, p-values corresponding to two tests are also provided in all of the tables. One of these tests is the Hansen Jtest for over-identifying restrictions and the other one is the AR (2) test for autocorrelation. The tests provide support for the exogeneity of the instruments and absence of autocorrelation in the specified order, respectively. Moreover, even in the static panel data setting, one might very much suspect the potential endogeneity of institutions and GDP per-capita as well as other control variables used in the above regression equation. Unfortunately, there is no consensus on 
what the right instrument for institutions and GDP per-capita are, especially in a panel data setting like ours. One shortcut we can conduct at this point is to estimate the equation above with instrument variable (IV) estimation using the lagged values of independent variables as instruments. We report the IV estimation results in the panel data estimation using these estimates.

Finally, to check for the long-run relationship between informal economy size and GDP per-capita we also have conducted regressions using the ordinary least squares (OLS) estimator where we simply run a cross-sectional regression using the average values for each country over the period of analysis. In the case of OLS estimations, to address the endogeneity issue, we also run an IV regression using several instrumental variables, namely latitude (Hall and Jones, 1999), an indicator variable for presidential vs. parliamentary regimes (Lederman et al. 2005), an indicator variable for transition countries, and indicator variables for the legal system (La Porta et al. 1999).

In the regressions, we will specifically be interested in the estimated coefficients of $\sigma_{1}$ and $\sigma_{2}$, where the former shows the direct relationship between informal economy size and GDP per-capita with institutional quality being held constant, whereas the latter represents the interaction of institutional quality with this relationship. Given our theoretical analysis, we expect, the estimated coefficients of $\sigma_{1}$ and $\sigma_{2}$ to be positive and negative, respectively.

\subsection{Data}

As mentioned in earlier sections, empirical studies on informality are rare. One such exception is the one constructed by Elgin and Oztunali (2012) for 161 countries over the period from 1950 to 2009. Considering the length of the time-series dimension we use this dataset for informal economy size. Moreover, we obtained the GDP per-capita series from Penn World Tables 7.1 (PWT). As for control variables we use, trade openness (defined as the ratio of the sum of exports and imports to GDP), government spending (as \% of GDP), capital- 
output ratio and growth of GDP per-capita. Similar to GDP per-capita, we obtained these variables from PWT. As measures of institutional quality, we use three institutional quality indices, i.e. corruption control, law and order and bureaucratic quality indices ${ }^{9}$. These indices are obtained from the International Country Risk Guide (ICRG) of the PRS Group and the rest of the variables from Penn World Tables 7.1. Unfortunately, the institutional quality indices are only available after 1984 and only for 141 countries $^{10}$, therefore, our data simply reduces 26 years for 141 countries from 1984 to 2009.

Table 1 provides descriptive statistics for all the variables used in the empirical analysis.

\section{Figures 3 and 4 about here}

To illustrate the plain correlation between informal economy size and GDP per-capita, in Figure 3 we plot shadow economy size as \% of GDP vs. GDP percapita. Here we plot average values for every country from 1950 to 2009. Even though Figure 3 suggest the existence of a highly negative (and linear) relationship between GDP per-capita and shadow economy size in a cross-section, there is also evidence leading us to suspect that this relationship might be non-linear. We illustrate this in Figure 4, where we group countries with respect to their GDP per-capita and then report the average GDP-weighted shadow economy size in each group for every year from 1960 to 2009. To do this, we divide the countries into five categories: poorest, second, third, fourth and the richest 20 \%. Not surprisingly, richer countries tend to have a smaller shadow economy; however what Figure 3 shows that this relationship might not be exactly linear, especially in the process of economic development. ${ }^{11}$

Figures 5 and 6 about here

\footnotetext{
${ }^{9}$ The choice of these three specific indices from ICRG stems from our conjecture that informality is mostly affected by these dimensions of institutional quality. (See Elgin, 2010 and Elgin and Solis-Garcia (2012) for examples of use of these indices for related environments. Moreover, these indices are also the ones that are most closely proxies by their theoretical counterparts $\left(\frac{\theta_{F}}{\theta_{I}}\right.$ and $\left.\rho\right)$ in the previous section.

${ }^{10}$ See the appendix for the list of countries used in the analysis

${ }^{11}$ Even tough, further research is required on this, this might be considered as a support for informality dimension of the Kuznets Curve hypothesis.
} 
Moreover, in figures 5 and 6 we illustrate the interaction of institutional quality with GDP per-capita. To plot these two figures, we first create a variable, titled institutions, which is defined as the weighted average of the three institutional quality indices we use in our regressions. Then, we simply divide our dataset into two based on the average value of this new variable. Figure 5 (6) plots informal economy size against GDP per-capita for countries below (above) the mean of this institutional quality variable. Observing that figures 5 and 6 resemble figures 1 and 2 from model simulations, we understand that our model, in terms of matching the plain correlations in the data, perform remarkably well.

\subsection{Estimation Results}

Table 2 reports first batch of regression results in which we use all the annual ${ }^{12}$ data for 141 countries from 1984 to 2009. We report in total nine regression results, eight using the FE estimator and a final one using the IV estimator. In the first five regressions, we use a variable titled "inst" among regressors, which is simply defined as the average of the three institutional quality measures we use. In the next three regressions, we use these three estimates separately and finally, we run an IV regression again using the variable "inst".

As expected, we observe that the estimated coefficients of the GDP percapita and the interaction term are positive and negative, respectively. This is so, when we use the interaction term (GDP - Inst.) of the institutions variable or the interaction terms with the three institutional quality variables separately. Results do not change qualitatively in any of the cases. Moreover, other than institutional quality, we observe that a higher rate of growth of GDP and capitaloutput ratio are robustly associated with a smaller informal economy size. This is not surprising as a higher capital intensity and growth rate would attract firms and households to the formal economy. On the other hand, trade openness and government spending are positively associated with informal economy

\footnotetext{
${ }^{12}$ Our results are robust when we use five-year averaged data to rule out business cycle effects.
} 
size in most regressions. Considering that with higher trade openness, formal enterprises may interlink their activities to the informal sector for the aim of cost reduction and increasing labor flexibility. Accordingly, openness might be viewed as a proxy that serves for the external subordination of the informal sector to the formal sector. As for government spending, a higher government spending possibly along with higher taxes might crowd out investment and capital-intensity and therefore imply a larger informal economy.

Tables 2, 3 and 4 about here

Moreover, in tables 3 and 4, we report regression results using the GMM and OLS estimators, respectively. In both cases, in all of the regressions the estimated coefficients of the GDP per-capita and the interaction term are positive and negative, respectively. Moreover, capital-output ratio and growth variables are significant in most regressions. All these indicate that our results are very much robust to the use of different estimators and to different econometric specifications.

\subsection{Further Robustness Checks}

\subsubsection{Different Periods and Countries}

In the first robustness check, we run regressions for different time period and countries. To this end, Table 5 reports two sets of regressions with FE, IV, GMM and OLS regressions for both subsets. In the first one, we only use data from 30 OECD countries $^{13}$ in our sample which have data for every year between 1984 and 2009. In the second subset, we then use the data from our whole dataset for years between 1992 and 2009 where all the countries included in the analysis exist. As indicated by the results reported in Table 5, our results are robust to this kind of stratification of the dataset.

\section{Table 5 about here}

\footnotetext{
${ }^{13}$ These are all the OECD members except Czech Republic, Estonia Slovenia, and Slovakia which did not exist prior to 1991 .
} 


\subsubsection{Different Informality Estimates}

In the next robustness check, we use a different dataset: Rather than the one provided by Elgin and Oztunali (2012) we use the shadow economy data presented by Buehn and Schneider (2012) which includes shadow economy series for 162 countries from 1999 to 2007. The result of these estimations are reported in Table 6. ${ }^{14}$ Notice that the Table 6 is constructed similar to the previous tables and we observe from this table that our results are fairly robust to the use of these different estimates of informality.

Table 6 about here

\subsubsection{Different Institutional Quality Measures}

As a final robustness check, we use different institutional quality measures other than ICRG series we used in the previous sections. These results are reported in Table 7. For this purpose, we obtain four specific series from the Worldwide Governance Indicators ${ }^{15}$ of the World Bank: Government Effectiveness (GE), Regulatory Quality (RQ), Rule of Law (RL) and Control of Corruption (CC). For space constraints, for this case, we only report the results of the FE estimation; however results using other estimators are qualitatively very similar.

\section{Table 7 about here}

\subsection{Summarizing the Empirical Results}

In the previous subsections of this section, we showed that higher GDP percapita levels are associated with larger informal sectors in countries with low institutional quality, whereas the size of the informal sector negatively depends on GDP per-capita in countries where institutional quality is high

One immediate question here might be, keeping the level of GDP per-capita constant, how important the quantitative influence of the quality of institutions

\footnotetext{
${ }^{14}$ For space constraints we only report the results of the FE estimation.

${ }^{15}$ See http://www.govindicators.org/or more information.
} 
on the shadow economy is. Specifically, we want to understand what the quantitative effect of a variation in the measure of institutions is.. To this end, in Table 8 , we report the $\%$ change informal economy size (relative to its mean) when we create a one standard-deviation variation in the respective institutional quality parameter. (corruption control, law and order and bureaucratic quality indices) When constructing this table we use the IV estimates of regressions where we used all the independent variables on the right hand side of the regressions.

\section{Table 9 about here}

Accordingly, for example a one standard deviation increase in the corruption control index (meaning a higher institutional quality) is associated with a $12.43 \%$ reduction of the informal economy size (as \% of its mean level reported in Table 1). We observe from from the table, that the effect of institutions vary for different institutional quality indices; nevertheless, Table 8 shows that informal sector size not only produces statistically significant coefficients but also has economically significant effects on default risk measures. Moreover, we also observe from Table 9 that the effect of institutions is smaller when we only focus on the OECD countries sample, rather than the whole dataset. This is

not surprising as we expect institutions to play a larger role when there is a more significant room for improvement, i.e. where the quality is low. Quantitatively, the most striking effect occurs in Latin America, whereas there are also significant effects of institutions on informal economy in Asia and Middle East and North Africa (MENA) countries as well.

\section{Concluding Remarks}

Compared to the economies of developed nations, emerging markets generally have a large informal economy which undermines effects of various policy tools and in that regard, hinders economic growth in these economies. In this paper, we, both theoretically and empirically, have investigated the relationship 
between the size of the informal economy and GDP per-capita by particularly taking their relationship with institutional quality into account. In the theoretical part of the paper, we developed a model of informal economy which suggests that the relationship between informal economy and economic development strongly interacts with proxies of institutional quality. Specifically, our model suggests that a higher level of GDP per-capital is associated with a larger informal economy size when the level of institutional quality is low and a smaller informal economy size when the level of institutional quality is high. We then conduct a thorough empirical analysis and observed that the data strongly supports what our model implies.

Our findings generally suggest that, without improvement in institutions, economic development alone does not lead to the phasing out of the informal economy. That is, policy makers should be concerned about institutional development as much as economic development. Institutional quality measures that significantly matter are all generally related to the effectiveness government policy. Specifically, they are corruption control, law and order (or rule of law), bureaucratic quality (or government effectiveness and regulatory quality) are highly important policy variables that, as indicated by the data, are significantly associated with informality.

Even though our paper is able to prescribe several policy recommendation at the macroeconomic level, as it is, it is silent about the exact microeconomic level mechanisms of how institutional quality is associated with the relationship between informal economy and GDP per-capita. This requires an in-depth analysis of firms and households at the face of making decisions whether to go informal or not. We leave these to future research. 


\section{References}

Aruoba, S.B. 2010. "Informal Sector, Government Policy and Institutions." 2010 Meeting Papers 324, Society for Economic Dynamics.

Blanchard, O., and J. Wolfers, 1999. "The Role of Shocks and Institutions in the Rise of European Unemployment: The Aggregate Evidence", NBER Working Papers No. 7282.

Buehn, A., and F. Schneider. 2012. "Shadow Economies around the World: Novel Insights, Accepted Knowledge, and New Estimates." International Tax and Public Finance 19 (1): 139-171.

Buehn, A. and F. Schneider, 2012. "Corruption and the shadow economy: like oil and vinegar, like water and fire?," International Tax and Public Finance, 19(1), 172-194.

Buehn, A., Lessmann, C., and G. Markwardt, 2013. "Decentralization and the shadow economy: Oates meets Allingham-Sandmo," Applied Economics, 45(18), 2567-2578.

Busato, F. and B. Chiarini, 2004. "Market and underground activities in a two-sector dynamic equilibrium model", Economic Theory, 23(4), 831-861.

Byiers, B. 2009. "Informality in Mozambique: Characteristics, Performance and Policy Issues". mimeo United States Agency for International Development.

Caro, L.; A.J. Galindo; and M. Melendez. 2012. "Credit, Labor Informality and Firm Performance in Colombia." IDB Working Paper No. IDB-WP-325, Inter-American Development Bank, Research Department.

Charles, S. W. 2011. "Institutional Quality and Economic Growth in Latin America", Global Economy Journal, 10 (4), 1524-61.

Crafts, N. and K. Kaiser, 2004. "Long-term growth prospect in transition economies: a reappraisal", Structural Change and Economic Dynamics, 15 (1), 101-118.

Dell'Anno, R. 2010. "Institutions and human development in the Latin American informal economy," Constitutional Political Economy, 21(3), 207- 
230.

Elgin, C. 2010. Political Turnover, Taxes and the Shadow Economy Working Papers 2010/08, Bogazici University, Department of Economics.

Elgin, C., and O. Oztunali. 2012. "Shadow Economies around the World: Model Based Estimates." Working Papers 2012/05, Bogazici University, Department of Economics.

Elgin, C. and M. Solis-Garcia. 2012. Public Trust, Taxes, and the Informal Sector. Bogazici Journal, 26 (1), 27-44.

Feld , L. P. and F. Schneider, 2010. "Survey on the Shadow Economy and Undeclared Earnings in OECD Countries," German Economic Review, Verein fur Socialpolitik, 11, 109-149.

Friedman, E.; S. Johnson; D. Kaufmann; and P. Zoido-Lobaton. 2000. "Dodging the Grabbing Hand: The Determinants of Unofficial Activity in 69 Countries." Journal of Public Economics 76, no. 3: 459-493.

Gatti, R., and M. Honorati. 2008. "Informality among Formal Firms : Firmlevel, Cross-country Evidence on Tax Compliance and Access to Credit." Policy Research Working Paper Series 4476, The World Bank.

Hall, R.E. and C. I. Jones, 1999. Why Do some Countries Produce so Much More Output Per Worker Than Others? Quarterly Journal of Economics, 114: 83-116.

Hart, K. 2008. "Informal Economy." In The New Palgrave Dictionary of Economics, ed. S.N. Durlauf, and L.E. Blume, pp. 845-846. Palgrave Macmillan.

Ihrig, J., and K. Moe. 2004. "Lurking in the Shadows: The Informal Sector and Government Policy." Journal of Development Economics 73, no. 2: 541557.

Johnson, S.; D. Kaufmann; and P. Zoido-Lobaton. 1998. "Regulatory Discretion and the Unofficial Economy." American Economic Review 88, no. 2: 387-92.

Koeda J., and E. Dabla-Norris. 2008. "Informality and Bank Credit: Evidence from Firm-Level Data." IMF Working Papers 08/94, International Mon- 
etary Fund.

LaPorta, R., F. Lopez-de-Silanes, A. Shleifer, and R. Vishny, 1999. The Quality of Government, Journal of Law, Economics and Organization, 15: 222279 .

La Porta, R., and A. Shleifer. 2008. "The Unofficial Economy and Economic Development." NBER Working Papers 14520, National Bureau of Economic Research, Inc.

Lederman, D., N. Loayza, and R.R. Soares, 2005. Accountability and Corruption: Political Institutions Matter, Economics and Politics, 17 (3): 1-35.

North, D. 1991. Institutions. Journal of Economic Perspectives, 5 (1), 97112.

Rajesh Raj, S.N. 2007. "Technical Efficiency in the Informal Manufacturing Enterprises: Firm Level Evidence from an Indian State." MPRA Paper 7816, University Library of Munich, Germany.

Roca, J. C. C., Moreno, C. D., J .E. G. Sanchez, 2001. "Underground economy and aggregate fluctuations", Spanish Economic Review, 3(1), 41-53.

Singh, A.; S. Jain-Chandra; and A. Mohommad. 2012. "Inclusive Growth, Institutions, and the Underground Economy." IMF Working Paper No. 12/47, International Monetary Fund.

Taymaz, E. 2009. "Informality and Productivity: Productivity Differentials between Formal and Informal Firms in Turkey." ERC Working Papers 0901, ERC - Economic Research Center, Middle East Technical University.

Torgler, B., and F. Schneider. 2009. "The Impact of Tax Morale and Institutional Quality on the Shadow Economy." Journal of Economic Psychology 30, no. 2: 228-245.

Schneider, F. and D. Teobaldelli, 2012. "Beyond the Veil of Ignorance: The Influence of Direct Democracy on the Shadow Economy," CESifo Working Paper Series 3749, CESifo Group Munich. 


\section{Appendix}

\section{Figures and Tables}

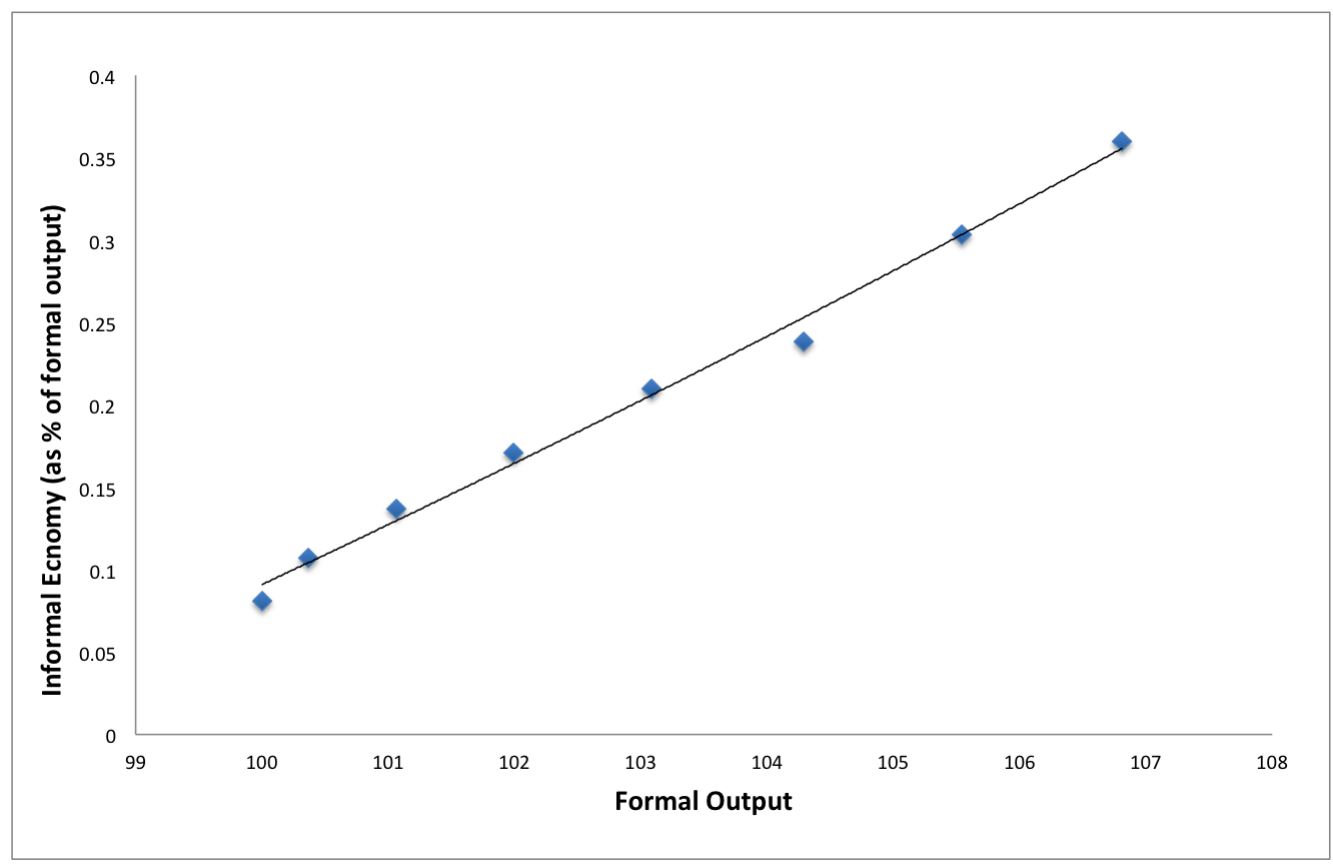

Figure 1: Informality vs. GDP per-capita in the Model: Bad Institutions

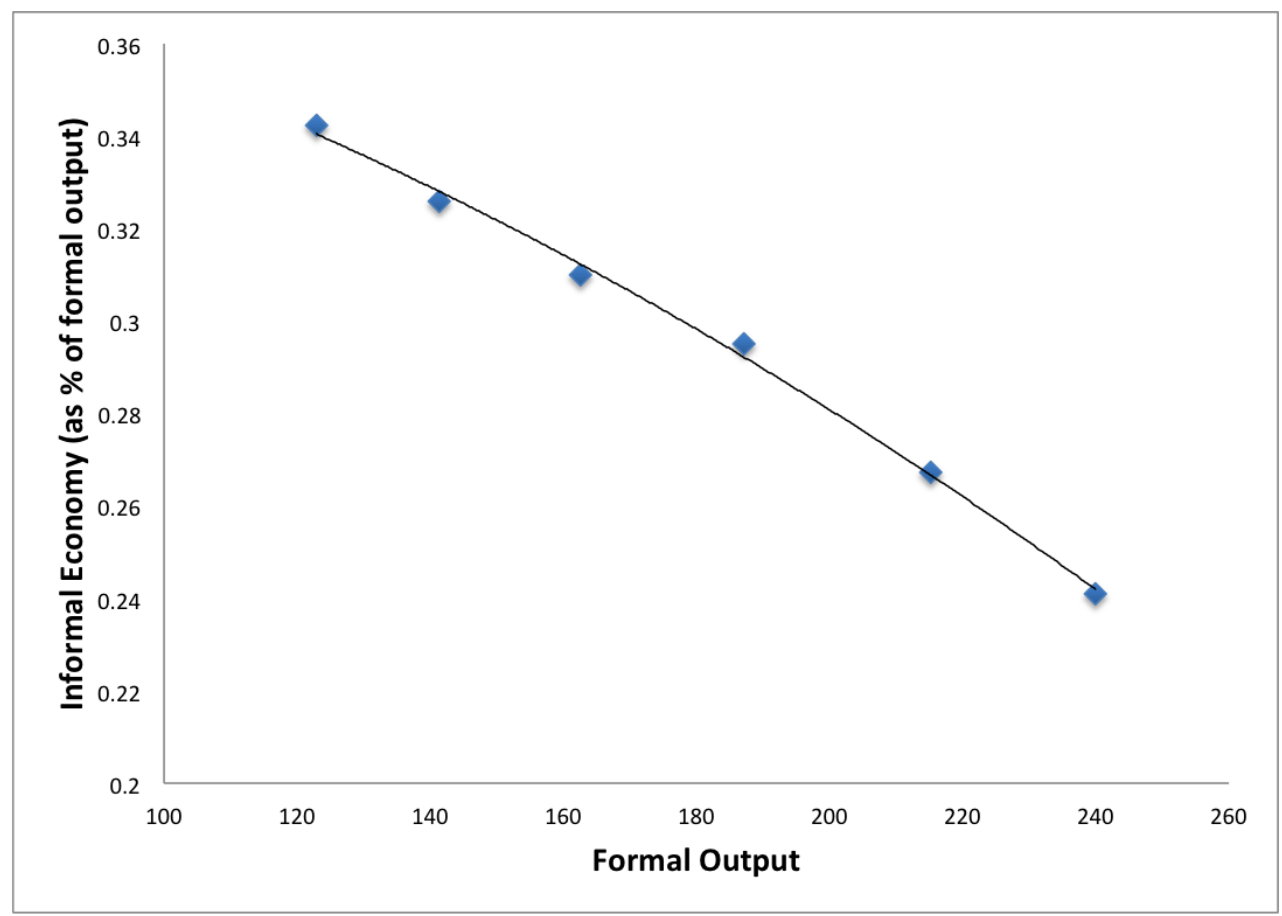

Figure 2: Informality vs. GDP per-capita in the Model: Good Institutions 


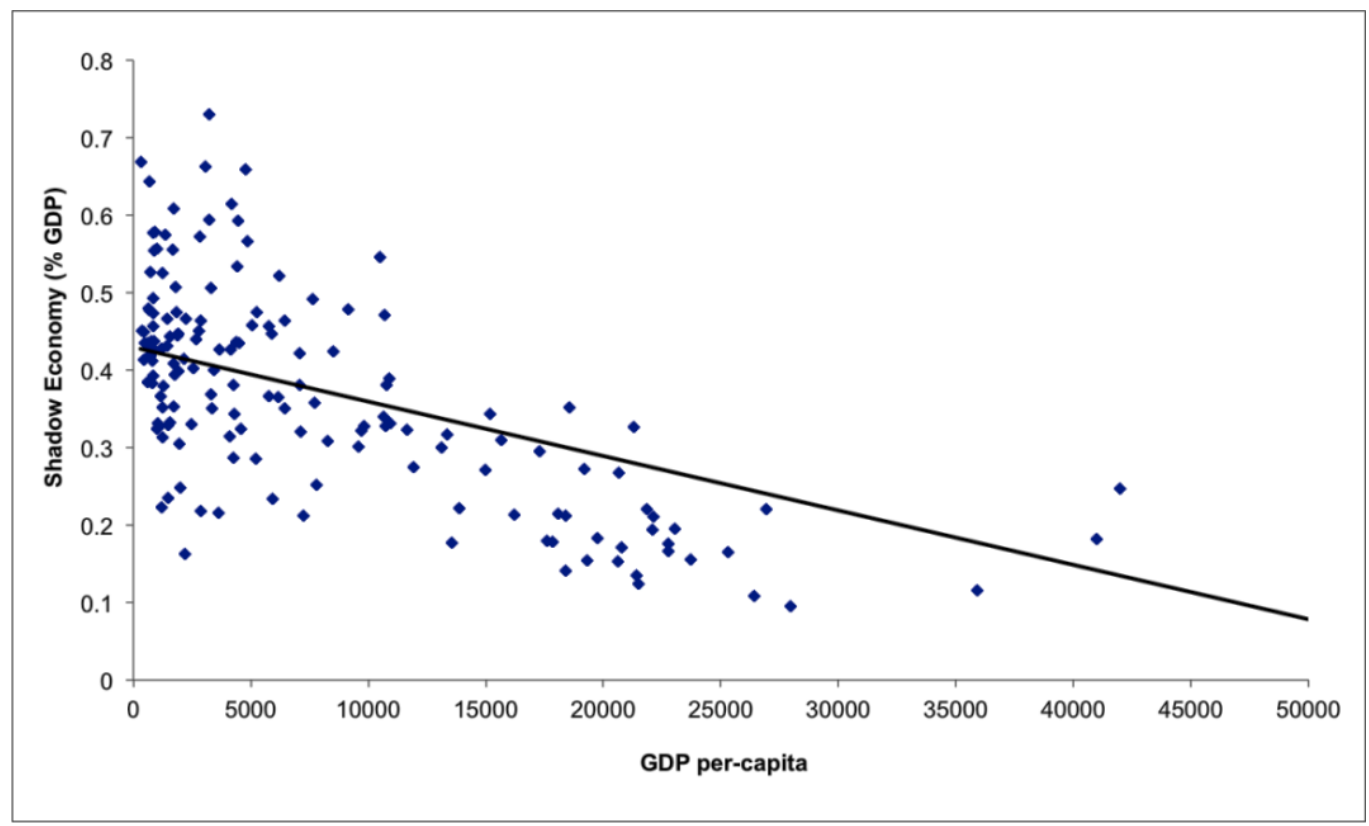

Figure 3: Informality and GDP per-capita

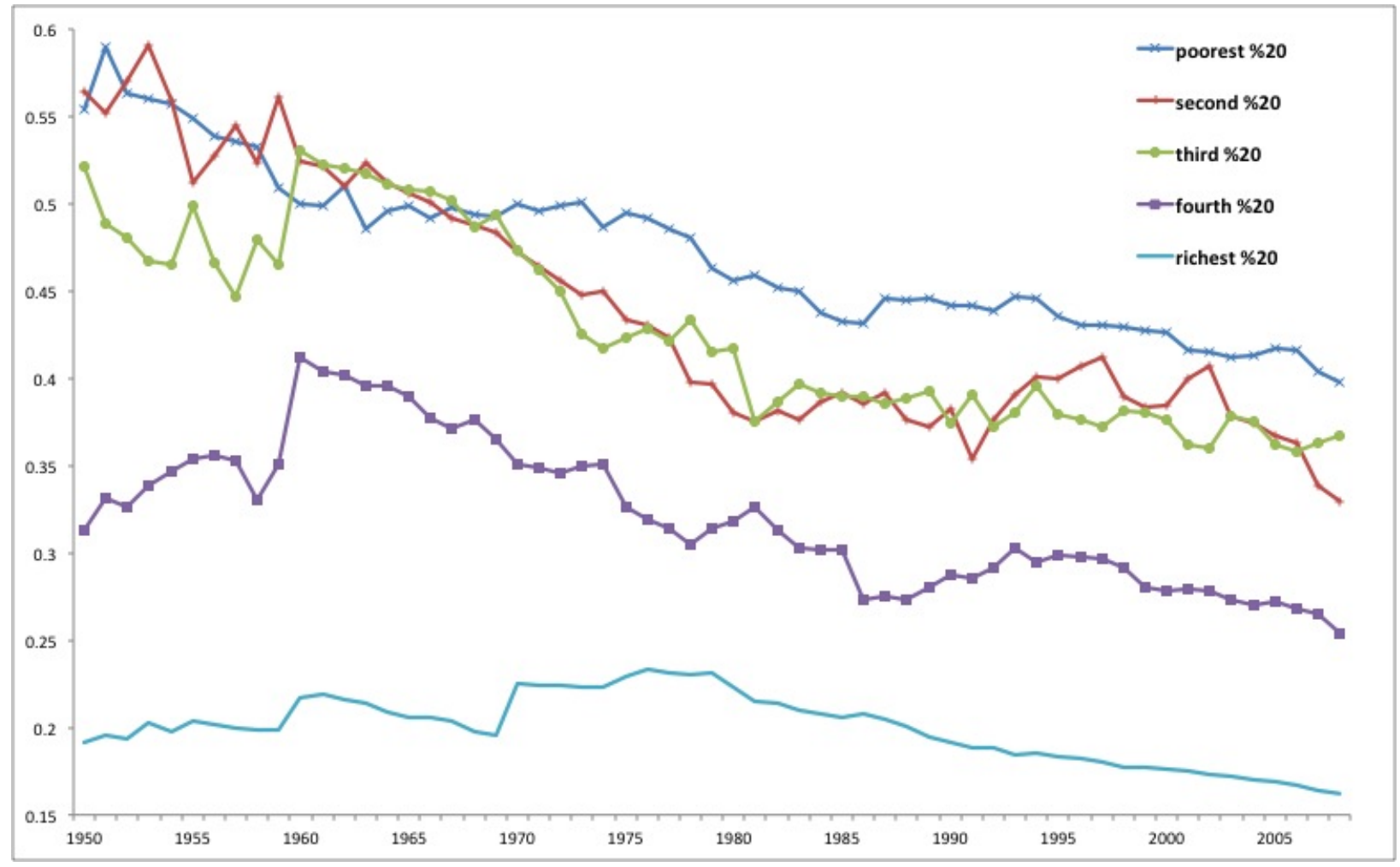

Figure 4: Informality in Different Income Groups 


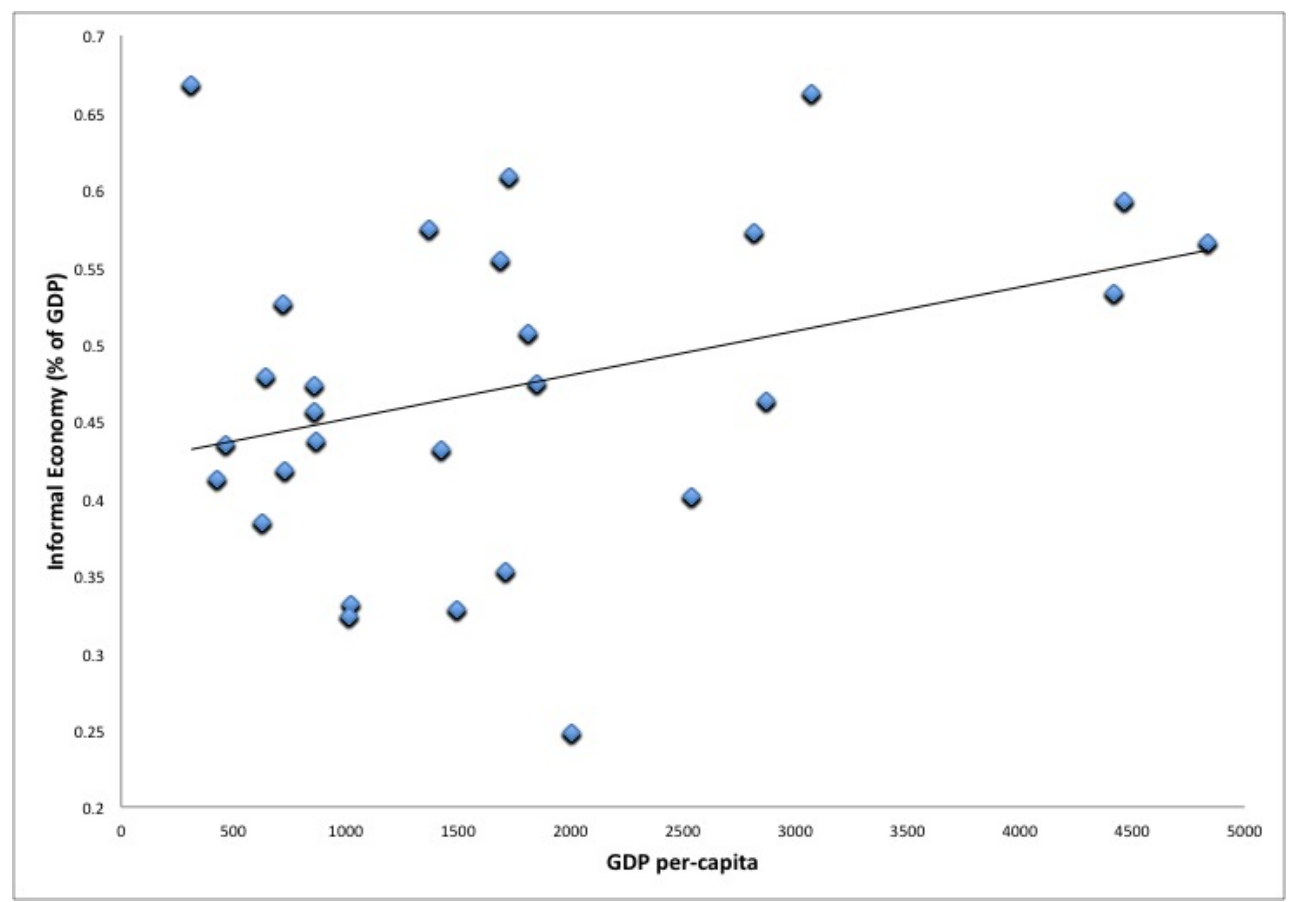

Figure 5: Informality vs. GDP per-capita in the Data: Bad Institutions

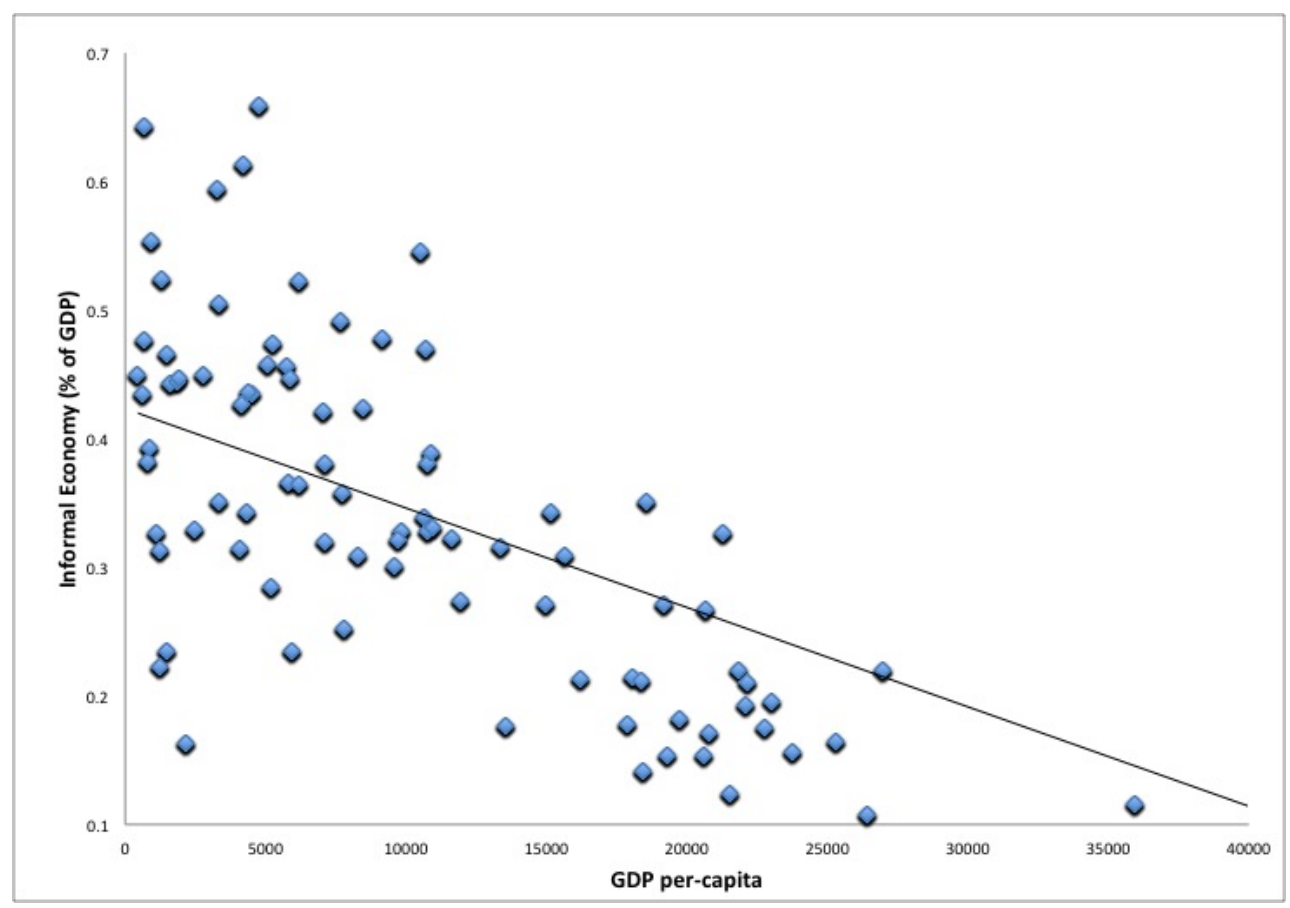

Figure 6: Informality vs. GDP per-capita in the Data: Good Institutions 
Table 1: Complete Dataset Summary Statistics

\begin{tabular}{lllll}
\hline \hline & Mean & Std. Dev. & Min. & Max. \\
\hline \hline Informal Economy (\% GDP) & 33.68 & 13.22 & 8.09 & 80.01 \\
GDP per-capita (thousand USD) & 10.22 & 12.93 & 0.15 & 125.37 \\
Trade Openness (\% GDP) & 78.86 & 49.49 & 8.36 & 415.28 \\
Government Spending (Govt. sp.) (\% GDP) & 11.09 & 7.03 & 1.75 & 56.48 \\
Capital-Output Ratio & 2.05 & 0.95 & 0.29 & 11.68 \\
Growth (\%) & 0.01 & 0.04 & -0.21 & 0.18 \\
\hline Corruption Control & 3.10 & 1.35 & 0.00 & 6.00 \\
Law and Order & 3.65 & 1.48 & 0.73 & 6.00 \\
Bureaucratic Quality & 2.16 & 1.19 & 0.00 & 4.00 \\
\hline \hline
\end{tabular}


Table 2: Informality vs. GDP per-capita: FE Estimations (All Years)

Informality

\begin{tabular}{|c|c|c|c|c|c|c|c|c|c|}
\hline & (1) & $(2)$ & $\overline{(3)}$ & $\overline{(4)}$ & $\overline{(5)}$ & $(6)$ & (7) & $(8)$ & $(\mathrm{IV})$ \\
\hline GDP & $\begin{array}{l}0.56^{*} \\
(3.31)\end{array}$ & $\begin{array}{l}0.50^{*} \\
(2.93)\end{array}$ & $\begin{array}{l}0.50^{*} \\
(2.94)\end{array}$ & $\begin{array}{l}0.49^{*} \\
(3.17)\end{array}$ & $\begin{array}{l}0.47^{*} \\
(3.22)\end{array}$ & $\begin{array}{l}0.28^{*} \\
(3.19)\end{array}$ & $\begin{array}{l}0.21^{* *} \\
(2.10)\end{array}$ & $\begin{array}{l}0.27^{*} \\
(2.88)\end{array}$ & $\begin{array}{l}0.34^{* *} \\
(2.10)\end{array}$ \\
\hline GDP - Inst. & $\begin{array}{c}-0.14^{*} \\
(7.59)\end{array}$ & $\begin{array}{c}-0.14^{*} \\
(7.28)\end{array}$ & $\begin{array}{c}-0.14^{*} \\
(7.31)\end{array}$ & $\begin{array}{c}-0.13^{*} \\
(8.08)\end{array}$ & $\begin{array}{c}-0.13^{*} \\
(8.26)\end{array}$ & & & & $\begin{array}{c}-0.16^{*} \\
(5.44)\end{array}$ \\
\hline Inst & $\begin{array}{l}0.18 \\
(0.86)\end{array}$ & $\begin{array}{l}0.22 \\
(0.84)\end{array}$ & $\begin{array}{l}0.24 \\
(0.77)\end{array}$ & $\begin{array}{l}0.27 \\
(0.79)\end{array}$ & $\begin{array}{l}0.29 \\
(0.81)\end{array}$ & $\begin{array}{c}-0.40 \\
(1.12)\end{array}$ & $\begin{array}{l}-0.51 \\
(0.71)\end{array}$ & $\begin{array}{c}-0.37 \\
(1.03)\end{array}$ & $\begin{array}{c}-0.04 \\
(0.40)\end{array}$ \\
\hline Openness & & $\begin{array}{l}0.01^{*} \\
(3.39)\end{array}$ & $\begin{array}{l}0.01^{*} \\
(3.38)\end{array}$ & $\begin{array}{l}0.03^{*} \\
(6.29)\end{array}$ & $\begin{array}{l}0.03^{*} \\
(6.75)\end{array}$ & $\begin{array}{l}0.03^{*} \\
(6.12)\end{array}$ & $\begin{array}{l}0.02^{*} \\
(6.24)\end{array}$ & $\begin{array}{l}0.03^{*} \\
(6.82)\end{array}$ & $\begin{array}{l}0.02^{* * *} \\
(1.80)\end{array}$ \\
\hline Govt. Sp. & & & $\begin{array}{l}0.01 \\
(0.26)\end{array}$ & $\begin{array}{l}0.09^{*} \\
(2.74)\end{array}$ & $\begin{array}{l}0.09^{*} \\
(2.66)\end{array}$ & $\begin{array}{l}0.08^{*} \\
(2.98)\end{array}$ & $\begin{array}{l}0.12^{*} \\
(3.45)\end{array}$ & $\begin{array}{l}0.11^{*} \\
(3.37)\end{array}$ & $\begin{array}{l}0.14^{* *} \\
(2.09)\end{array}$ \\
\hline Capital & & & & $\begin{array}{c}-3.37^{*} \\
(4.85)\end{array}$ & $\begin{array}{c}-3.57^{*} \\
(4.84)\end{array}$ & $\begin{array}{c}-3.17^{*} \\
(4.45)\end{array}$ & $\begin{array}{c}-3.67^{*} \\
(4.90)\end{array}$ & $\begin{array}{c}-3.72^{*} \\
(4.92)\end{array}$ & $\begin{array}{c}-2.99^{*} \\
(3.01)\end{array}$ \\
\hline Growth & & & & & $\begin{array}{l}-17.38^{*} \\
(4.60)\end{array}$ & $\begin{array}{l}-15.93^{*} \\
(4.64)\end{array}$ & $\begin{array}{l}-18.43^{*} \\
(4.74)\end{array}$ & $\begin{array}{l}-19.03^{*} \\
(4.75)\end{array}$ & $\begin{array}{c}-9.10^{*} \\
(2.89)\end{array}$ \\
\hline GDP · Law & & & & & & $\begin{array}{c}-0.31^{*} \\
(4.78)\end{array}$ & & & \\
\hline GDP · Corr. & & & & & & & $\begin{array}{c}-0.30^{*} \\
(6.81)\end{array}$ & & \\
\hline GDP ·Bur. & & & & & & & & $\begin{array}{l}-0.25^{*} \\
(7.10)\end{array}$ & \\
\hline$R$-squared & 0.47 & 0.47 & 0.47 & 0.51 & 0.52 & 0.20 & 0.52 & 0.53 & 0.30 \\
\hline Observations & 2756 & 2756 & 2756 & 2593 & 2593 & 2593 & 2593 & 2593 & 2452 \\
\hline F-Test & 0.00 & 0.00 & 0.00 & 0.00 & 0.00 & 0.00 & 0.00 & 0.00 & \\
\hline J-Test & & & & & & & & & 0.18 \\
\hline AR (2)-Test & & & & & & & & & 0.40 \\
\hline
\end{tabular}

All panel regressions include a country fixed effect and year dummies. Absolute values of robust t-statistics are reported in parentheses. $*, * *, * * *$ denote 1,5 and $10 \%$ confidence levels, respectively. IV refers to instrumental variable regression. 
Table 3: Informality vs. GDP per-capita: GMM Estimations (All Years)

Informality

\begin{tabular}{lllllllll}
\hline \hline & $(1)$ & $(2)$ & $(3)$ & $(4)$ & $(5)$ & $(6)$ & $(7)$ & $(8)$ \\
\hline \hline GDP & $0.36^{*}$ & $0.41^{*}$ & $0.40^{*}$ & $0.38^{*}$ & $0.37^{*}$ & $0.18^{*}$ & $0.14^{*}$ & $0.19^{* *}$ \\
& $(2.90)$ & $(2.73)$ & $(2.74)$ & $(2.67)$ & $(2.62)$ & $(3.09)$ & $(2.60)$ & $(2.01)$ \\
GDP · Inst. & $-0.17^{*}$ & $-0.16^{*}$ & $-0.16^{*}$ & $-0.16^{*}$ & $-0.16^{*}$ & & & \\
& $(6.90)$ & $(6.78)$ & $(6.71)$ & $(6.68)$ & $(6.61)$ & & & \\
Inst. & -0.32 & -0.41 & -0.40 & $0-.46$ & -0.39 & -0.99 & -0.81 & -0.03 \\
& $(0.66)$ & $(0.64)$ & $(0.65)$ & $(0.69)$ & $(0.71)$ & $(1.32)$ & $(1.01)$ & $(0.83)$ \\
Openness & & $0.03^{*}$ & $0.03^{*}$ & $0.03^{*}$ & $0.04^{*}$ & $0.04^{*}$ & $0.04^{*}$ & $0.04^{*}$ \\
& & $(3.09)$ & $(3.08)$ & $(3.08)$ & $(3.05)$ & $(3.06)$ & $(3.10)$ & $(3.12)$ \\
Govt. Sp. & & & 0.09 & 0.10 & 0.11 & -0.02 & 0.04 & -0.01 \\
& & & $(0.40)$ & $(0.45)$ & $(0.47)$ & $(0.98)$ & $(0.29)$ & $(0.37)$ \\
Capital & & & & $-2.97^{*}$ & $-2.95^{*}$ & $-2.77^{*}$ & $-2.61^{*}$ & $-2.84^{*}$ \\
& & & & $(3.99)$ & $(3.94)$ & $(3.74)$ & $(3.70)$ & $(4.01)$ \\
Growth & & & & & $-9.30^{*}$ & $-9.39^{*}$ & $-10.01^{*}$ & $-10.13^{*}$ \\
& & & & & $(3.06)$ & $(3.01)$ & $(2.94)$ & $(2.90)$ \\
GDP · Law & & & & & & $-0.17^{*}$ & & \\
GDP · Corr. & & & & & & $(3.78)$ & & $-0.19^{*}$ \\
& & & & & & & $(3.80)$ & \\
GDP ·Bur. & & & & & & & & $-0.15^{*}$ \\
& & & & & & & & $(3.65)$ \\
L. Informality & $0.70^{* *}$ & $0.71^{* *}$ & $0.71^{* *}$ & $0.78^{* *}$ & $0.77^{* *}$ & $0.68^{* *}$ & $0.61^{* *}$ & $0.27^{* * *}$ \\
& $(2.01)$ & $(2.03)$ & $(2.04)$ & $(2.07)$ & $(2.02)$ & $(1.99)$ & $(2.10)$ & $(1.75)$ \\
\hline \hline Observations & 2474 & 2474 & 2474 & 2474 & 2311 & 2311 & 2311 & 2311 \\
J-Test & 0.23 & 0.25 & 0.24 & 0.20 & 0.21 & 0.33 & 0.37 & 0.35 \\
AR (2) Test & 0.44 & 0.42 & 0.40 & 0.28 & 0.22 & 0.32 & 0.26 & 0.28 \\
\hline
\end{tabular}

All panel regressions include a country fixed effect and year dummies. Robust z-statistics are reported in parentheses. $*, * *, * * *$ denote 1,5 and $10 \%$ confidence levels, respectively. In all regressions a constant is also included but not reported. 
Table 4: Informality vs. GDP per-capita: OLS Estimations (Mean values)

\begin{tabular}{|c|c|c|c|c|c|c|c|c|c|}
\hline & $(1)$ & $(2)$ & $(3)$ & $(4)$ & $(5)$ & $(6)$ & $(7)$ & $(8)$ & (IV) \\
\hline GDP & $\begin{array}{l}0.52^{*} \\
(4.86)\end{array}$ & $\begin{array}{l}0.52^{*} \\
(4.84)\end{array}$ & $\begin{array}{l}0.53^{*} \\
(4.77)\end{array}$ & $\begin{array}{l}0.47^{*} \\
(4.39)\end{array}$ & $\begin{array}{l}0.46^{*} \\
(4.11)\end{array}$ & $\begin{array}{l}0.40^{*} \\
(4.12)\end{array}$ & $\begin{array}{l}0.41^{*} \\
(4.01)\end{array}$ & $\begin{array}{l}0.47^{*} \\
(4.03)\end{array}$ & $\begin{array}{l}0.39^{*} \\
(4.09)\end{array}$ \\
\hline GDP · Inst. & $\begin{array}{l}-0.12^{*} \\
(6.50)\end{array}$ & $\begin{array}{l}-0.12^{*} \\
(6.92)\end{array}$ & $\begin{array}{l}-0.12^{*} \\
(6.83)\end{array}$ & $\begin{array}{l}-0.12^{*} \\
(7.13)\end{array}$ & $\begin{array}{l}-0.12^{*} \\
(6.16)\end{array}$ & & & & $\begin{array}{l}-0.09^{*} \\
(5.74)\end{array}$ \\
\hline Inst. & $\begin{array}{l}1.02 \\
(1.16)\end{array}$ & $\begin{array}{l}1.52 \\
(1.14)\end{array}$ & $\begin{array}{l}1.53 \\
(1.06)\end{array}$ & $\begin{array}{l}1.37 \\
(1.09)\end{array}$ & $\begin{array}{l}1.16 \\
(1.13)\end{array}$ & $\begin{array}{l}0.97 \\
(1.00)\end{array}$ & $\begin{array}{l}0.91 \\
(0.95)\end{array}$ & $\begin{array}{l}0.47 \\
(0.73)\end{array}$ & $\begin{array}{l}-0.04^{* * *} \\
(1.72)\end{array}$ \\
\hline Openness & & $\begin{array}{l}0.01 \\
(1.07)\end{array}$ & $\begin{array}{l}0.01 \\
(1.30)\end{array}$ & $\begin{array}{l}0.03^{*} \\
(2.99)\end{array}$ & $\begin{array}{l}0.03^{*} \\
(3.00)\end{array}$ & $\begin{array}{l}0.03^{*} \\
(3.02)\end{array}$ & $\begin{array}{l}0.03^{*} \\
(3.01)\end{array}$ & $\begin{array}{l}0.03^{*} \\
(3.09)\end{array}$ & $\begin{array}{l}-0.04^{* * *} \\
(1.79)\end{array}$ \\
\hline Govt. Sp. & & & $\begin{array}{l}-0.09 \\
(1.42)\end{array}$ & $\begin{array}{l}-0.06 \\
(1.05)\end{array}$ & $\begin{array}{l}-0.06 \\
(1.05)\end{array}$ & $\begin{array}{l}-0.06 \\
(1.08)\end{array}$ & $\begin{array}{l}-0.07 \\
(1.05)\end{array}$ & $\begin{array}{l}-0.06 \\
(1.06)\end{array}$ & $\begin{array}{l}-0.04 \\
(1.00)\end{array}$ \\
\hline Capital & & & & $\begin{array}{l}-2.45^{*} \\
(5.78)\end{array}$ & $\begin{array}{l}-2.42^{*} \\
(5.70)\end{array}$ & $\begin{array}{l}-2.40^{*} \\
(5.71)\end{array}$ & $\begin{array}{l}-2.43^{*} \\
(5.72)\end{array}$ & $\begin{array}{l}-2.49^{*} \\
(5.72)\end{array}$ & $\begin{array}{l}-3.04^{*} \\
(4.99)\end{array}$ \\
\hline Growth & & & & & $\begin{array}{l}-12.06 \\
(0.32)\end{array}$ & $\begin{array}{l}-12.03 \\
(0.41)\end{array}$ & $\begin{array}{c}-11.99 \\
(0.43)\end{array}$ & $\begin{array}{l}-12.01 \\
(0.35)\end{array}$ & $\begin{array}{l}-9.76^{* *} \\
(2.12)\end{array}$ \\
\hline GDP $\cdot$ Law & & & & & & $\begin{array}{l}-0.09^{* *} \\
(2.08)\end{array}$ & & & \\
\hline GDP - Corr. & & & & & & & $\begin{array}{l}-0.14^{* *} \\
(2.10)\end{array}$ & & \\
\hline GDP ·Bur. & & & & & & & & $\begin{array}{l}-0.20^{*} \\
(3.09)\end{array}$ & \\
\hline$\overline{R \text {-squared }}$ & $\overline{00.46}$ & $\overline{0.46}$ & 0.46 & $\overline{00.52}$ & 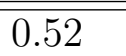 & $\overline{00.52}$ & $\overline{00.52}$ & $\overline{00.53}$ & 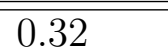 \\
\hline Observations & 141 & 141 & 141 & 141 & 141 & 141 & 141 & 141 & 141 \\
\hline F-Test & 0.00 & 0.00 & 0.00 & 0.00 .20 & 0.00 & 0.00 & 0.00 & 0.00 & 0.00 \\
\hline
\end{tabular}

All panel regressions include a country fixed effect and year dummies. Absolute values of robust t-statistics are reported in parentheses. ${ }^{*},{ }^{* *},{ }^{* * *}$ denote 1,5 and $10 \%$ confidence levels, respectively. IV refers to instrumental variable regression 
Table 5: Informality vs. GDP per-capita: FE Estimations (All Years) - Different Periods and Countries

\begin{tabular}{|c|c|c|c|c|c|c|c|c|}
\hline & \multicolumn{4}{|c|}{ OECD: 1984-2009 } & \multicolumn{4}{|c|}{ All: 1992-2009 } \\
\hline & $\mathrm{FE}$ & IV & GMM & OLS & $\mathrm{FE}$ & IV & GMM & OLS \\
\hline GDP & $\begin{array}{l}0.26^{*} \\
(3.04)\end{array}$ & $\begin{array}{l}0.24^{*} \\
(3.17)\end{array}$ & $\begin{array}{l}0.29^{* *} \\
(2.11)\end{array}$ & $\begin{array}{l}0.17^{*} \\
(3.09)\end{array}$ & $\begin{array}{l}0.67^{*} \\
(4.33)\end{array}$ & $\begin{array}{l}0.68^{*} \\
(4.29)\end{array}$ & $\begin{array}{l}0.65^{*} \\
(3.10)\end{array}$ & $\begin{array}{l}0.77^{*} \\
(3.75)\end{array}$ \\
\hline GDP · Inst. & $\begin{array}{l}-0.19^{*} \\
(4.92)\end{array}$ & $\begin{array}{l}-0.20^{*} \\
(4.88)\end{array}$ & $\begin{array}{l}-0.21^{*} \\
(4.81)\end{array}$ & $\begin{array}{l}-0.23^{*} \\
(4.08)\end{array}$ & $\begin{array}{l}-0.14^{*} \\
(5.54)\end{array}$ & $\begin{array}{l}-0.15^{*} \\
(5.54)\end{array}$ & $\begin{array}{l}-0.12^{*} \\
(4.40)\end{array}$ & $\begin{array}{c}-0.17^{*} \\
(3.87)\end{array}$ \\
\hline Inst & $\begin{array}{l}0.08 \\
(0.43)\end{array}$ & $\begin{array}{l}0.12 \\
(0.24)\end{array}$ & $\begin{array}{l}0.22 \\
(0.57)\end{array}$ & $\begin{array}{l}0.99 \\
(1.01)\end{array}$ & $\begin{array}{l}0.14 \\
(1.04)\end{array}$ & $\begin{array}{l}0.11 \\
(0.68)\end{array}$ & $\begin{array}{l}0.09 \\
(0.51)\end{array}$ & $\begin{array}{l}0.07 \\
(0.83)\end{array}$ \\
\hline Openness & $\begin{array}{l}-0.02^{* * *} \\
(1.75)\end{array}$ & $\begin{array}{l}-0.02^{* *} \\
(2.09)\end{array}$ & $\begin{array}{c}-0.01^{*} \\
(3.08)\end{array}$ & $\begin{array}{l}-0.01^{* *} \\
(2.00)\end{array}$ & $\begin{array}{l}0.01^{*} \\
(4.75)\end{array}$ & $\begin{array}{l}0.01^{*} \\
(3.20)\end{array}$ & $\begin{array}{l}0.01^{*} \\
(3.24)\end{array}$ & $\begin{array}{l}0.02^{* *} \\
(2.02)\end{array}$ \\
\hline Govt. Sp. & $\begin{array}{l}0.07 \\
(0.19)\end{array}$ & $\begin{array}{l}0.10 \\
(0.33)\end{array}$ & $\begin{array}{l}0.04 \\
(0.36)\end{array}$ & $\begin{array}{l}0.08 \\
(0.48)\end{array}$ & $\begin{array}{l}0.09^{*} \\
(2.66)\end{array}$ & $\begin{array}{l}0.08^{*} \\
(2.98)\end{array}$ & $\begin{array}{l}0.12^{*} \\
(3.45)\end{array}$ & $\begin{array}{l}0.11^{*} \\
(3.37)\end{array}$ \\
\hline Capital & $\begin{array}{l}-1.75^{*} \\
(2.89)\end{array}$ & $\begin{array}{l}-1.99^{*} \\
(3.01)\end{array}$ & $\begin{array}{l}-2.01^{*} \\
(3.10)\end{array}$ & $\begin{array}{l}-2.10^{*} \\
(3.25)\end{array}$ & $\begin{array}{l}-3.86^{*} \\
(3.11)\end{array}$ & $\begin{array}{l}-3.72^{*} \\
(3.65)\end{array}$ & $\begin{array}{l}-3.89^{*} \\
(3.97)\end{array}$ & $\begin{array}{l}-3.80^{*} \\
(3.90)\end{array}$ \\
\hline Growth & $\begin{array}{l}-6.12^{*} \\
(3.27)\end{array}$ & $\begin{array}{l}-5.90^{*} \\
(3.08)\end{array}$ & $\begin{array}{l}-3.78^{*} \\
(3.11)\end{array}$ & $\begin{array}{l}-4.01 \\
(3.19)\end{array}$ & $\begin{array}{l}-9.96^{*} \\
(4.18)\end{array}$ & $\begin{array}{c}-11.04^{*} \\
(4.43)\end{array}$ & $\begin{array}{l}-14.12^{*} \\
(4.30)\end{array}$ & $\begin{array}{c}-14.21^{*} \\
(4.54)\end{array}$ \\
\hline L. Informality & & & $\begin{array}{l}0.89^{*} \\
(4.01)\end{array}$ & & & & $\begin{array}{l}1.02^{*} \\
(3.99)\end{array}$ & \\
\hline$\overline{R \text {-squared }}$ & 0.46 & 0.49 & & $\overline{0.41}$ & $\overline{0.44}$ & 0.40 & $\overline{00}$ & 0.43 \\
\hline Observations & 780 & 639 & 498 & 30 & 1712 & 1570 & 1429 & 141 \\
\hline F-Test & 0.00 & & & 0.00 & 0.00 & & & 0.00 \\
\hline J-Test & & 0.20 & 0.21 & & & 0.19 & 0.34 & \\
\hline AR (2)-Test & & 0.18 & 0.32 & & 0.18 & 0.41 & & \\
\hline
\end{tabular}

All panel regressions include a country fixed effect and year dummies. Absolute values of robust t-statistics are reported in parentheses. ${ }^{*}, * *, * * *$ denote 1,5 and $10 \%$ confidence levels, respectively. FE, IV, GM and OLS refer to fixed-effects, instrumental variable, generalized method of moments and ordinary least squares regressions, respectively. 
Table 6: Informality vs. GDP per-capita: FE Estimations (All Years) - Different Informality Data

Informality

\begin{tabular}{|c|c|c|c|c|c|c|c|c|c|}
\hline & $(1)$ & $(2)$ & $(3)$ & $(4)$ & $(5)$ & $(6)$ & $(7)$ & $(8)$ & (IV) \\
\hline GDP & $\begin{array}{l}0.54^{*} \\
(3.20)\end{array}$ & $\begin{array}{l}0.52^{*} \\
(2.80)\end{array}$ & $\begin{array}{l}0.51^{*} \\
(2.84)\end{array}$ & $\begin{array}{l}0.54^{*} \\
(2.98)\end{array}$ & $\begin{array}{l}0.57^{*} \\
(3.01)\end{array}$ & $\begin{array}{l}0.32^{*} \\
(3.10)\end{array}$ & $\begin{array}{l}0.31^{*} \\
(2.76)\end{array}$ & $\begin{array}{l}0.25^{*} \\
(2.69)\end{array}$ & $\begin{array}{l}0.37^{*} \\
(3.01)\end{array}$ \\
\hline GDP - Inst. & $\begin{array}{l}-0.15^{*} \\
(7.56)\end{array}$ & $\begin{array}{l}-0.15^{*} \\
(7.28)\end{array}$ & $\begin{array}{l}-0.15^{*} \\
(7.31)\end{array}$ & $\begin{array}{l}-0.13^{*} \\
(8.08)\end{array}$ & $\begin{array}{l}-0.14^{*} \\
(8.25)\end{array}$ & & & & $\begin{array}{l}-0.22^{*} \\
(6.21)\end{array}$ \\
\hline Inst & $\begin{array}{l}0.23^{* * *} \\
(1.74)\end{array}$ & $\begin{array}{l}0.22 \\
(1.54)\end{array}$ & $\begin{array}{l}0.20 \\
(1.47)\end{array}$ & $\begin{array}{l}0.21 \\
(1.39)\end{array}$ & $\begin{array}{l}0.29 \\
(0.81)\end{array}$ & $\begin{array}{l}-0.09 \\
(1.10)\end{array}$ & $\begin{array}{l}-0.11 \\
(0.91)\end{array}$ & $\begin{array}{l}-0.27 \\
(0.85)\end{array}$ & $\begin{array}{l}-0.14^{* * *} \\
(1.74)\end{array}$ \\
\hline Openness & & $\begin{array}{l}0.01^{*} \\
(3.09)\end{array}$ & $\begin{array}{l}0.01^{*} \\
(3.30)\end{array}$ & $\begin{array}{l}0.02^{*} \\
(3.19)\end{array}$ & $\begin{array}{l}0.02^{*} \\
(3.45)\end{array}$ & $\begin{array}{l}0.02^{*} \\
(3.51)\end{array}$ & $\begin{array}{l}0.02^{*} \\
(4.04)\end{array}$ & $\begin{array}{l}0.03^{*} \\
(5.29)\end{array}$ & $\begin{array}{l}0.02^{* *} \\
(2.01)\end{array}$ \\
\hline Govt. Sp. & & & $\begin{array}{l}0.01 \\
(0.26)\end{array}$ & $\begin{array}{l}0.04^{* * * *} \\
(1.74)\end{array}$ & $\begin{array}{l}0.05^{* *} \\
(1.86)\end{array}$ & $\begin{array}{l}0.07^{* *} \\
(1.98)\end{array}$ & $\begin{array}{l}0.09 * * \\
(2.05)\end{array}$ & $\begin{array}{l}0.10^{* *} \\
(2.07)\end{array}$ & $\begin{array}{l}0.05^{*} \\
(3.01)\end{array}$ \\
\hline Capital & & & & $\begin{array}{l}-3.36^{*} \\
(4.15)\end{array}$ & $\begin{array}{l}-3.29^{*} \\
(4.14)\end{array}$ & $\begin{array}{l}-3.19^{*} \\
(4.15)\end{array}$ & $\begin{array}{c}-3.20^{*} \\
(4.10)\end{array}$ & $\begin{array}{l}-3.12^{*} \\
(4.02)\end{array}$ & $\begin{array}{l}-4.07^{*} \\
(4.24)\end{array}$ \\
\hline Growth & & & & & $\begin{array}{l}-13.19^{*} \\
(4.38)\end{array}$ & $\begin{array}{l}-13.32^{*} \\
(4.33)\end{array}$ & $\begin{array}{l}-13.27^{*} \\
(4.47)\end{array}$ & $\begin{array}{l}-13.06^{*} \\
(4.50)\end{array}$ & $\begin{array}{l}-12.11^{*} \\
(4.44)\end{array}$ \\
\hline GDP · Law & & & & & & $\begin{array}{l}-0.27^{* *} \\
(2.38)\end{array}$ & & & \\
\hline GDP · Corr. & & & & & & & $\begin{array}{l}-0.33^{*} \\
(5.80)\end{array}$ & & \\
\hline GDP ·Bur. & & & & & & & & $\begin{array}{l}-0.32^{*} \\
(5.49)\end{array}$ & \\
\hline $\bar{R} R$-squared & 0.44 & 0.45 & $\overline{0.46}$ & 0.50 & $\overline{0.53}$ & 0.24 & 0.22 & 0.26 & 0.42 \\
\hline Observations & 1269 & 1269 & 1269 & 1269 & 1269 & 1269 & 1269 & 1269 & 1128 \\
\hline F-Test & 0.00 & 0.00 & 0.00 & 0.00 & 0.00 & 0.00 & 0.00 & 0.00 & \\
\hline J-Test & & & & & & & & & 0.34 \\
\hline AR (2)-Test & & & & & & & & & 0.30 \\
\hline
\end{tabular}

All panel regressions include a country fixed effect and year dummies. Absolute values of robust t-statistics are reported in parentheses. ${ }^{*}, * *, * * *$ denote 1,5 and $10 \%$ confidence levels, respectively. IV refers to instrumental variable regression 
Table 7: Informality vs. GDP per-capita: FE Estimations (All Years) - Different Institutional Measures

Informality

\begin{tabular}{lll|ll|ll|ll}
\hline \hline & GE & \multicolumn{3}{l}{ RQ } & \multicolumn{2}{l}{ RL } & \\
\hline & FE & IV & FE & IV & FE & IV & FE & IV \\
\hline \hline GDP & $0.53^{*}$ & $0.49^{*}$ & $0.41^{*}$ & $0.44^{*}$ & $0.39^{*}$ & $0.36^{*}$ & $0.41^{*}$ & $0.34^{*}$ \\
& $(3.10)$ & $(2.71)$ & $(3.44)$ & $(3.08)$ & $(3.41)$ & $(3.70)$ & $(3.16)$ & $(3.03)$ \\
GDP $\cdot$ Inst. & $-0.29^{* *}$ & $-0.32^{* *}$ & $-0.21^{*}$ & $-0.23^{*}$ & $-0.22^{*}$ & $-0.24^{*}$ & $-0.30^{*}$ & -0.38 \\
& $(2.34)$ & $(2.28)$ & $(4.11)$ & $(4.08)$ & $(5.12)$ & $(3.70)$ & $(4.34)$ & $(3.01)$ \\
Inst & 0.10 & 0.12 & 0.50 & 0.64 & 0.41 & -0.39 & $-0.11^{* * *}$ & $-0.27^{* * *}$ \\
& $(0.40)$ & $(0.61)$ & $(1.00)$ & $(1.08)$ & $(1.17)$ & $(1.36)$ & $(1.70)$ & $(1.81)$ \\
Openness & $0.02^{*}$ & $0.01^{*}$ & $0.01^{*}$ & $0.01^{*}$ & $0.01^{*}$ & $0.02^{*}$ & $0.02^{*}$ & $0.02^{*}$ \\
& $(3.11)$ & $(3.09)$ & $(3.32)$ & $(3.08)$ & $(3.45)$ & $(3.41)$ & $(3.04)$ & $(3.29)$ \\
Govt. Sp. & 0.09 & 0.11 & 0.18 & 0.04 & 0.05 & 0.07 & 0.09 & 0.13 \\
& $(0.46$ & $(0.70)$ & $(0.66)$ & $(0.74)$ & $(0.86)$ & $(0.88)$ & $(1.50)$ & $(1.07)$ \\
Capital & $-2.99^{*}$ & $3.14^{*}$ & -3.21 & $-3.28^{*}$ & $-3.17^{*}$ & $-3.06^{*}$ & $-2.20^{*}$ & $-3.32^{*}$ \\
& $(3.12)$ & $(3.30)$ & $(3.06)$ & $(2.99)$ & $(3.41)$ & $(3.30)$ & $(3.17)$ & $(3.02)$ \\
Growth & $-7.19^{*}$ & $-9.29^{*}$ & -10.33 & -11.12 & $-12.18^{*}$ & $-12.32^{*}$ & $-11.55^{*}$ & $-12.61^{*}$ \\
& $(4.45)$ & $(4.52)$ & $(4.38)$ & $(4.40)$ & $(4.29)$ & $(4.33)$ & $(4.37)$ & $(4.53)$ \\
\hline \hline$R$-squared & 0.37 & 0.35 & 0.43 & 0.48 & 0.23 & 0.31 & 0.24 & 0.30 \\
Observations & 1949 & 1806 & 1949 & 1806 & 1949 & 1806 & 1949 & 1806 \\
F-Test & 0.00 & 0.00 & 0.00 & 0.00 & 0.00 & 0.00 & 0.00 & 0.00 \\
J-Test & & 0.24 & & 0.28 & & 0.33 & & 0.30 \\
AR (2)-Test & & 0.18 & & 0.19 & & 0.21 & & 0.24 \\
\hline
\end{tabular}

All panel regressions include a country fixed effect and year dummies. Absolute values of robust t-statistics are reported in parentheses. ${ }^{*}, * *, * * *$ denote 1,5 and $10 \%$ confidence levels, respectively. FE and IV refer to fixed-effects and instrumental variable regressions. Institutional quality measures used as the relevant independent variable are Government Effectiveness (GE), Regulatory Quality (RQ), Rule of Law (RL) and Control of Corruption (CC)

Table 8: Quantifying Effect of Institutions on Informality

\begin{tabular}{cccc}
\hline \hline Variable & Corruption & Law and Order & Bur. Qual. \\
\hline \hline Whole Data (1984-2009) & 12.43 & 13.18 & 8.83 \\
Whole Data (1992-2009) & 13.11 & 15.10 & 11.25 \\
OECD (1984-2009) & 8.24 & 9.18 & 7.85 \\
Latin America (1984-2009) & 16.14 & 19.18 & 13.15 \\
Asia (1984-2009) & 13.07 & 16.04 & 9.85 \\
MENA (1984-2009) & 9.90 & 11.20 & 9.12 \\
\hline \hline
\end{tabular}




\section{List of Countries}

OECD-EU: Australia, Austria, Belgium, Canada, Chile, Cyprus, Denmark, Finland, France, Germany, Greece, Iceland, Ireland, Israel, Italy, Japan, Korea (South), Luxemburg, Malta, Mexico, Netherlands, New Zealand, Norway, Portugal, Spain, Sweden, Switzerland, Turkey, UK, USA

Latin American and Caribbean: Argentina, Bahamas, Bolivia, Brazil, Colombia, Costa Rica, Dominican Republic, Ecuador, El Salvador, Guatemala, Guyana, Honduras, Jamaica, Nicaragua, Panama, Paraguay, Peru, Suriname, Trinidad and Tobago, Uruguay, Venezuela,

Post-Socialist: Albania, Armenia, Azerbaijan, Belarus, Bosnia and Herzegovina, Bulgaria, Croatia, Czech Republic, Estonia, Georgia, Hungary, Kazakhstan, Kyrgyzstan, Latvia, Lithuania, Moldova, Mongolia, Poland, Romania, Russia, Slovakia, Slovenia, Ukraine,

MENA: Algeria, Bahrain, Egypt, Iran, Jordan, Kuwait, Lebanon, Libya, Morocco, Oman, Qatar, Saudi Arabia, Syria, Tunisia, UAE, Yemen,

Sub-saharan Africa: Angola, Botswana, Burkina Faso, Cameroon, Democratic Republic of Congo, Republic of Congo, Equatorial Guinea, Ethiopia, Gabon, Gambia, Ghana, Guinea, Guinea-Bissau, Ivory Coast, Kenya, Liberia, Madagascar, Malawi, Mali, Mozambique, Namibia, Niger, Nigeria, Senegal, Sierra Leone, South Africa, Sudan, Tanzania, Togo, Uganda, Zambia, Zimbabwe.

Asia - Oceania: Bangladesh, Brunei, Cambodia, China, Fiji, Hong Kong, India, Indonesia, , Malaysia, Nepal, Pakistan, Papua New Guinea, Philippines, Singapore, Sri Lanka, Taiwan, Thailand, Vietnam, 